\title{
PREEKLAMPSIJOS IR LĖTINIO PERIODONTITO RYŠYS
}

\author{
Ingrida Marija Pacauskienė, Eglė Stasiukonė, Benita Vaišvilaitė \\ Lietuvos sveikatos mokslu universitetas
}

Raktažodžiai: lètinis periodontitas, preeklampsija, priešlaikinis gimdymas, mažo svorio naujagimiai.

\section{Santrauka}

Ši literatūros apžvalga ịvertina lètinio periodontito galimybę sukelti vieną iš didžiausių nèštumo komplikacijų - preeklampsiją bei apydančio būklès ịtaką nèštumo eigai. Mokslinès literatūros apžvalgai atrinkti straipsniai, publikuoti 2002-2014 metais. Paieškai naudotos duomenų bazès PubMed (www. ncbi.nlm.nih.gov/pubmed), „Journal of Periodontology“" (www.joponline.org). Apžvelgta 19 studijų, tyrusių lètinio periodontito ir preeklampsijos ryšį ir 3 literatūros apžvalgos. Itrauktos 5 studijos, analizavusios uždegimo ịtaką preeklampsija sergančioms nėščiosioms, bei 10 tyrimų apie lètinio periodontito ir nèštumo komplikacijų ryšį. Analizuotuose literatūros šaltiniuose ryšys tarp lètinio periodontito ir preeklampsija sergančių néščiųjų patvirtinimas 17 studijų. 5 studijos ryši paneigia. Tyrimų rezultatai patvirtina lètinio periodontito itaką besilaukiančioms moterims, sergančioms preeklampsija. 6 studijos įrodo lètinio periodontito galimybę sukelti nëštumo komplikacijas, 4 paneigia. Dèl skirtingu studijų metodologijų, nehomogeniškų imčių, lètinio periodontito ir preeklampsijos vertinimo kriteriju neatitikimo, reikia atlikti išsamesnes studijas, galèsiančias pateikti tikslesnius rezultatus.

\section{Ivadas}

Išsivysčiusiose šalyse preeklampsijos paplitimas 2-7 proc., neišsivysčiusiose - daugiau nei 10 proc. Pastarosiose tai dažniausia néščiujų mirties priežastis. Néščiujų hipertenzijos dažnumas Lietuvoje - 7 proc., preeklampsijos -2 proc. 75 proc. sergančiujų preeklampsija - pirmą kartą gimdančios [51]. Šis susirgimas laikomas viena sunkiausių komplikacijų akušerijoje dèl spartaus vystymosi ir baigčiu mirtimi. Daugelio studiju autoriai kelia hipotezę, kad pagrindinị vaidmenị preeklampsijos etiologijoje atlieka infekcija, sukeldama sisteminę uždegiminę reakciją ar pablo- gindama esamą būklę $[3,7,10,12]$. Apydančio ligos įvardijamos kaip galimai reikšmingas etiologinis preeklampsijos išsivystymo veiksnys.

Jau 1994 m. irodyta, kad periopatogenai veikia nëštumo eigą ir vaisiaus būklę [9]. Studiją su žmonèmis $1996 \mathrm{~m}$. pirmą kartą atliko Offenbacher S. ir kt [32]. Nuo tada periodonto ir nėštumo patologijos ryšys plačiai tyrinejjamas.

Straipsnio tikslas: apžvelgti 2002-2014 metų mokslinę literatūrą, analizuojančią preeklampsijos ir periodontito ryšị.

\section{Tyrimo objektas ir metodai}

Tyrimo objektas: preeklampsija ir periodontitas. Tyrimo metodai: mokslinès literatūros analizè.

Preeklampsija - specifinis su nëštumu susijęs sindromas. Tai grèsminga motinos ir vaisiaus būklè, pasireiškianti hipertenzija, proteinurija, edemomis. Ši daugiasisteminè patologija būdinga po 20 savaičių néštumo. Preeklampsija vis dar plačiai tiriama, kadangi jos etiologija ir patofiziologija iki galo neaiški. Rizikos veiksniai, nulemiantys preeklamsijos išsivystymą - néščiųų amžius (15-20; 40-45 metų), pirmasis nëštumas, daugiavaisis nèštumas, paveldimumas, inkstų ligos, cukrinis diabetas, lètinè hipertenzija, socialinè padètis, rasè [39]. Daugelio studijų autoriai teigia, jog infekcija atlieka svarbų vaidmeni preeklampsijos etiologijoje ir kelia klausimą, ar lètinis periodontitas yra reikšmingas šios patologijos išsivystymo veiksnys.

Moksliniai tyrimai ir literatūros apžvalgos atrinkti iš MEDLINE PubMed, Journal of Periodontology duomenų bazių, pasirenkant 2002-2014 metus. Paieškos sistemoje naudoti raktiniai žodžiai ,periodontitis “, ,preeclampsia“, ",preterm birth “, ,, low birth weight". Atlikus paiešką, rastas 431 šaltinis. Jie atitiko straipsnio temą savo pavadinimu ir anotacija. 400 šaltinių neturèjo pagrindinio raktažodžio „preeclampsia” ir buvo atmesti. Papildomai informacijai naudoti straipsniai is $P u b M e d$ (www.ncbi.nlm.nih.gov/pubmed), Science Direct, Web Of Science, Journal Of Periodontology" (www.joponline.org) duomenų bazių.

Lètinis periodontitas - infekcinè apydančio audinių liga, sutrikdanti dantenų vagelès apsauginę funkciją ir su- 
kelianti organizmo ląstelių uždegimini atsaką prieš bakterijas. Uždegimo pažeistų dantenų spenelių ir išopejjusios vagelès audinių plotas siekia $8-20 \mathrm{~cm}^{2}$. Čia vyksta bakterijų ir jų fragmentų - lipopolisacharidų (LPS) - skverbimasis į cirkuliacinę sistemą. Uždegiminiuose apydančio audiniuose išsiskiria didelis kiekis citokinų: interleukinas $-1 \beta$ (IL-1 $\beta$ ), interleukinas - 6 (IL-6), prostaglandinas E2 (PG E2) ir naviko nekrozès faktorius $\alpha$ (TNF- $\alpha$ ) [3, $28,33,34,49]$. Manoma, kad infekcija apydančio audiniuose sukuria hematogeninius vartus bakterijoms, endotoksinams ir uždegiminiams faktoriams išsisèti kraujotakos sistemoje, kraujo keliu pasiekti placentą ir inicijuoti sistemini uždegimini atsaką [26,42]. Per pažeistą dantenų vagelę patekę ị kraujotaką, jie žaloja něščiosios organizmą, didina oksidacinį stresą, kuris citotoksiškai veikia kraujagyslių endoteli $[3,40]$. Šis reiškinys ypač dažnas nèštumo metu dèl hormonų pasikeitimo padidejjusio kraujagyslių pralaidumo. Vykstant imuniniam-uždegiminiam atsakui gali būti pažeidžiamas placentos kraujagyslių tinklas, sutrikdoma normali kraujo tékmé, kyla kraujo spaudimas - inicijuojama preeklampsijos būsena [26].

Dažniausi periodontito sukèlëjai gramneigiami mikroorganizmai: Aggregatibacter actinomycetemcomitans (A. actinomycetemcomitans), Porphyromonas gingivalis ( $P$. gingivalis), Prevotella intermedia (P. intermedia), Tannerella forsythia (T. forsythia), Fusobacterium nucleatum (F. nucleatum), gramteigiami - Parvimonas micra (P. micra) [48]. Moterims, sergančioms preeklampsija, dantenų vagelèse dažniau aptinkamos $P$. gingivalis, T. forsythia, E.corrodens [10]. Eksperimentinès studijos rodo, kad $P$. gingivalis turi įtakos néštumo metu pasitaikančioms komplikacijoms [22,23]. Ši gramneigiama bakterija aptinka-

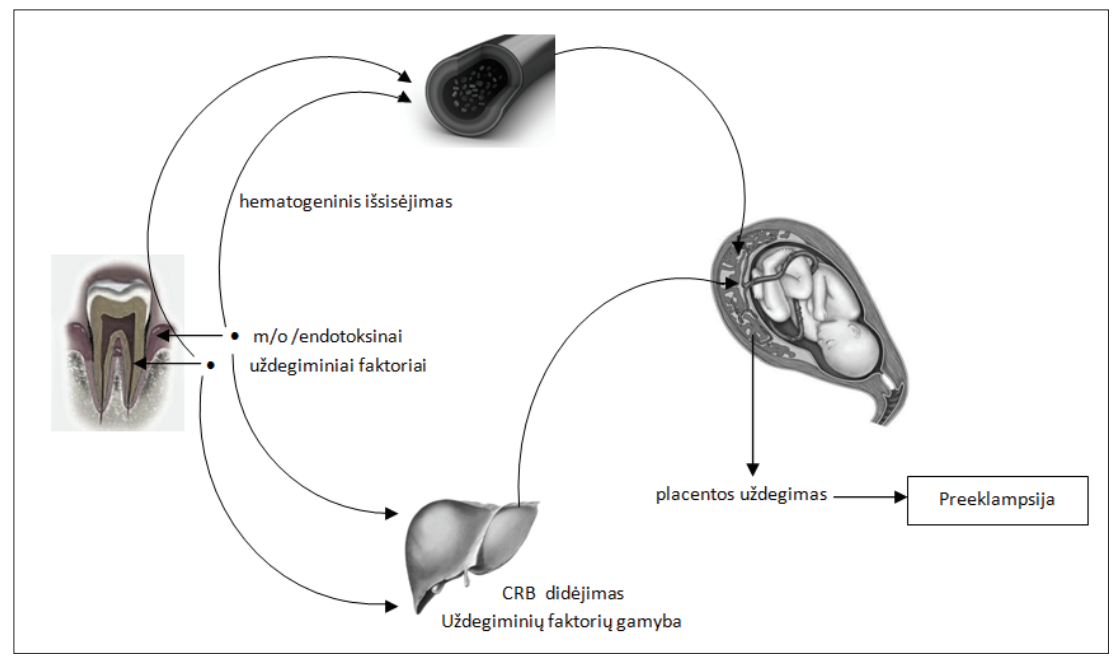

1 pav. Biologinis modelis ma kraujotakos sistemoje. Ji išskiria cisteino proteinazes, skatinančias krešejimo faktorių aktyvinimą ir trombocitu agregaciją [25,36], veikiančias virkštelès venų endoteliocitų citokinų išsiskyrimą [7]. P.gingivalis aktyvuoja kepenų ląsteles ir periferinius kraujo monocitus, o tai skatina uždegiminių veiksnių (IL-1, IL-6, TNF- $\alpha$ ) gamybą ir išskyrimą $[14,21]$. T.forsythia išskiria lipopolisacharidus ir ị tripsiną panašią proteinazę, prasiskverbiančią i i ląsteles ir skatinančią jų apoptozę $[1,29]$.

Preeklampsijos ir lėtinio periodontito ryšys mokslinėje literatūroje. Pastarujų metų periodontito, preeklampsijos ir sisteminių uždegimo veiksnių studijos nustatè, kad periodontitas kliniškai susijęs su preeklampsija $[7,24,37,46]$.

Uždegiminiai veiksniai ar mikroorganizmai iš periodonto audinių ị placentą patenka dviem keliais [42] (1 pav.).

1. Tiesioginis kelias:

a) išsisejja kraujotakos sistemoje ir taip pasiekia placentą;

b) gali pasiekti placentą kylančiu keliu per lytinę - šalinimo sistemą.

2. Netiesioginis kelias:

a) iš apydančio audinių išsiskyrę uždegimo mediatoriai cirkuliuodami veikia placentą;

b) uždegimo mediatoriai ir/arba mikroorganizmų komponentai patenka ị kepenis, ten didina uždegiminių veiksnių gamybą, ūmų baltyminị atsaką ( CRB), o pastarieji veikia placentą.

Jau 1994 m. įrodyta, kad periopatogenai gali turèti ìtakos gyvūnų nèštumo eigai ir vaisiaus būklei [9]. 1996 $\mathrm{m}$. S. Offenbacher su bendraautoriais pirmieji tyrè moterų apydančio uždegimo ir néštumo patologijos ryši [32]. Pirma studija, aprašiusi periodontito galimybę sukelti preeklampsiją, paskelbta 2003 m. [3]. Mokslinių tyrimų duomenys apie létinio periodontito ir preeklamsijos ryši iki šiol yra prieštaringi. Skirtingoms tyrimų išvadoms priežasčių gali būti daug: nėra standartinio periodontito apibrèžimo, metodikos klaidos, skirtingų populiacijų studijos. Apžvelgus atliktus tyrimus, išsiskiria dvi grupès: tiriantys periodontito ir preeklampsijos ryšį, ir tiriantys, kaip periodontitas keičia sergančiųju preeklampsija nèštumo eigą.

2003 m. K. A. Boggess su bendraautoriais nustate, jog néščiosioms buvo didesné rizika susirgti preeklamsija, jei jos sirgo sunkiu lètiniu 
periodontitu (galimybių santykis (OR 2,4), arba nëštumo metu periodontitas progresavo (OR 2,1) [4]. Vèliau atlikta eilè tyrimų, kurių metu apžiūrint burnos ertmę ir vertinant periodontologinius duomenis - kišenès gylị (PD), kraujavimą zonduojant (BOP), klinikinès jungties aukštis (CAL), gauti rezultatai susieti su preeklampsijos etiologija $[3,6,12,14,19,30,41,50]$. A. Kunnen ir kt. (2010) atliko mokslinès literatūros apžvalgą, kurioje teigiama, kad aštuonios tiriamosios studijos nustate ryši tarp periodontito ir preeklampsijos, tuo tarpu keturios nerado statistiškai patikimo ryšio [19].
Sergančiujų lètiniu periodontitu placentose dažniau aptinkami šios ligos sukèlejai. Barak ir kt. (2007) ištyrè preeklampsija sergančių ir sveikų nėščiujų placentos mèginius, paimtus po cezario operacijos. $50 \%$ sergančiujų preeklampsija ir tik $14 \%$ sveikujų placentoje aptiktas bent vienas periopatogenas. Tai rodo periodontito ir preeklampsijos ryšị [4]. Pastaraisiais metais atlikti keli tyrimai, nustatę sąsajas tarp placentose rastų A.actinomycetemcomitans, $P$. gingivalis, P. intermedia, T. forsythia, F. nucleatum, T. denticola ir hipertenzijos nèštumo metu $[8,45]$.

Rūkymas turi įtakos tiek lètinio periodontito, tiek pree-

1 lentelè. Periodontito ir preeklamsijos ryšys (naujausių studijų rezultatai)

\begin{tabular}{|c|c|c|c|c|c|c|}
\hline $\begin{array}{l}\text { Autorius, } \\
\text { metai }\end{array}$ & Šalis & Populiacija & Amžius & $\begin{array}{l}\text { Preeklampsijos } \\
\text { požymiai }\end{array}$ & $\begin{array}{l}\text { Periodontito } \\
\text { požymiai }\end{array}$ & Išvados \\
\hline $\begin{array}{l}\text { Sayar F., } \\
2011[41]\end{array}$ & Iranas & $\begin{array}{l}105 \mathrm{PE} \\
105 \\
\text { kontrolè }\end{array}$ & - & $\begin{array}{c}\mathrm{AKS} \geq 140 / 90 \mathrm{mmHg} \text { ir } \\
\mathrm{PU} 1+\end{array}$ & $\begin{array}{c}\text { Silpnas CAL } \leq 2 \mathrm{~mm} \\
\text { Vidutinis CAL } \\
\leq 3 \mathrm{~mm} \\
\text { Sunkus CAL } \geq 3 \mathrm{~mm}\end{array}$ & $\begin{array}{l}\text { CAL sergančiujų } \\
\text { preeklampsija } \\
\text { grupèje buvo } \\
\text { ženkliai didesnis }\end{array}$ \\
\hline $\begin{array}{l}\text { Horton A. } \\
\text { L., 2010 } \\
\quad[15]\end{array}$ & USA & $\begin{array}{l}34 \mathrm{PE} \\
757 \\
\text { kontrolè }\end{array}$ & $\begin{array}{l}\text { PE } 26,3 \\
\quad \pm 6,1 \\
\text { kontrolè } \\
28,2 \pm 6,5\end{array}$ & $\begin{array}{l}\text { AKS }>140 / 90 \mathrm{mmHg} \text { ir } \\
\geq 1+\text { PU surinkiklyje }\end{array}$ & $\begin{array}{c}\text { Silpnas }-<15 \\
\text { paviršių su } \geq 1 \mathrm{PD} \\
\geq 4 \mathrm{~mm} \text { arba } \geq 1 \mathrm{PP} \\
\text { su } \mathrm{BOP} \\
\text { Sunkus }-\geq 15 \\
\text { paviršiu } \mathrm{PD} \geq 4 \mathrm{~mm}\end{array}$ & $\begin{array}{l}\text { Periodontitas } \\
\text { nedidina } \\
\text { preeklampsijos } \\
\text { rizikos }\end{array}$ \\
\hline $\begin{array}{l}\text { Ha J. E., } \\
2011[13]\end{array}$ & Korèja & $\begin{array}{c}16 \mathrm{PE} \\
48 \text { kontrolè }\end{array}$ & $\begin{array}{c}\mathrm{PE} \\
32,69 \pm 5,30 \\
\text { kontrole } \\
32,69 \pm 4,40\end{array}$ & $\begin{array}{c}2 \mathrm{k} \text { AKS }>140 / 90 \mathrm{mmHg} \\
\text { ir } \geq 1+\mathrm{PU}\end{array}$ & $\begin{array}{c}\text { Lokalus PD }-2-3 \\
\text { paviršiai CAL } \geq 3,5 \\
\text { mm } \\
\text { Generalizuotas PD } \\
-\geq 4 \text { skirtingų dantu } \\
\text { paviršiai CAL } \geq 3,5 \\
\text { mm }\end{array}$ & $\begin{array}{l}\text { Periodontitas gali } \\
\text { būti patikimai } \\
\text { susietas su } \\
\text { preeklampsija }\end{array}$ \\
\hline $\begin{array}{l}\text { Taghzouti } \\
\text { N.,2012 } \\
{[46]}\end{array}$ & Kanada & $\begin{array}{l}92 \mathrm{PE} \\
245 \\
\text { kontrolè }\end{array}$ & - & $\begin{array}{c}\text { SKS }>140 \mathrm{mmHg} \text { arba } \\
\text { DKS }>90 \mathrm{mmHg} \text { ir } \geq 1+ \\
\text { PU }\end{array}$ & $\begin{array}{l}\geq 4 \text { paviršiai su } \\
P P D \geq 5 \mathrm{~mm} \text { ir } \\
\text { CAL } \geq 3 \mathrm{~mm} \text { tuo } \\
\text { pačiu metu }\end{array}$ & $\begin{array}{l}\text { Nerasta patikimo } \\
\text { ryšio tarp } \\
\text { periodontito ir } \\
\text { preeklampsijos }\end{array}$ \\
\hline $\begin{array}{l}\text { Politano } \\
\text { G. T., } \\
2011[37]\end{array}$ & Brazilija & $\begin{array}{c}58 \mathrm{PE} \\
58 \text { kontrolè }\end{array}$ & $\begin{array}{c}\text { PE 28,62 } \\
\text { 6,93 } \\
\text { Kontrole } \\
24,69 \pm 5,37\end{array}$ & $\begin{array}{c}\text { SKS } \geq 140 \mathrm{mmHg} \text { arba } \\
\text { DKS } \geq 90 \mathrm{mmHg} \text { po } 20 \\
\text { savaičiu nëštumo ir PU } \\
\geq 300 \mathrm{mg}\end{array}$ & $\begin{array}{c}\geq 2 \text { paviršiai } \mathrm{PD} \geq 4 \\
\mathrm{~mm}, \mathrm{CAL} \geq 4 \mathrm{~mm} \text { ir } \\
\mathrm{BOP}\end{array}$ & $\begin{array}{c}\text { Nustatytas } \\
\text { patikimas ryšys } \\
\text { tarp periodontito in } \\
\text { preeklampsijos }\end{array}$ \\
\hline $\begin{array}{l}\text { Yoseffin } \\
\text { O., 2011 } \\
{[50]}\end{array}$ & Indonezija & $\begin{array}{c}26 \mathrm{PE} \\
26 \text { kontrolè }\end{array}$ & $20-39$ & $\begin{array}{l}\mathrm{SKS} \geq 140 \mathrm{mmHg} \text { arba } \\
\mathrm{DKS} \geq 90 \mathrm{mmHg}, \mathrm{PU}\end{array}$ & $\begin{array}{c}\text { Silpnas }-\mathrm{CAL} \geq 3 \\
\text { mm } 3 \text { paviršiuose } \geq 3 \\
\text { skirtinguose dantyse } \\
\text { Vidutinis }-\mathrm{CAL} \geq 5 \\
\text { mm, } 3 \text { paviršiuose } \geq 3 \\
\text { skirtinguose dantyse } \\
\text { Sunkus }- \text { CAL } \geq 7 \\
\text { mm, } 3 \text { paviršiuose } \geq 3 \\
\text { skirtinguose dantyse }\end{array}$ & $\begin{array}{c}\text { PE grupejje } \\
\text { periodontitas } \\
\text { diagnozuotas } 3,17 \\
\text { karto dažniau } \\
\text { nei kontrolinėje } \\
\text { grupejje }\end{array}$ \\
\hline $\begin{array}{l}\text { Lafzi A., } \\
2011[20]\end{array}$ & Iranas & $\begin{array}{l}30 \mathrm{PE} \\
30 \text { kontrolè }\end{array}$ & $\begin{array}{c}\text { PE } 24,5 \pm \\
2,6 \\
\text { Kontrolė } \\
21,5 \pm 2,1\end{array}$ & $\begin{array}{l}\text { SKS }>140 \mathrm{mmHg} \text { arba } \\
\text { DKS }>90 \mathrm{mmHg}, \mathrm{PU} \\
0,3 \mathrm{~g} / 24 \mathrm{~h}, 2 \mathrm{k} \geq 4 \mathrm{~h}\end{array}$ & $\begin{array}{c}\mathrm{PB} \geq 3 \mathrm{~mm}, \mathrm{CAL} \geq 3 \\
\mathrm{~mm}\end{array}$ & $\begin{array}{c}\text { Nerasta patikimo } \\
\text { periodontito ir } \\
\text { preeklampsijos } \\
\text { ryšio }\end{array}$ \\
\hline
\end{tabular}


klampsijos išsivystymui. 2014 m. Jung-Eun H. su bendraautoriais tyrè niekada nerūkiusias nëščiąsias. Ištirtos 283 moterys -67 sergančios lètiniu periodontitu ir 216 sveikų. Paaiškejo, kad moterims, kurioms diagnozuotas lètinis periodontitas, preeklampsija išsivyste 5 kartus dažniau, nei periodontologiškai sveikoms (OR 5,56) [17]. Šis tyrimas svarbus tuo, jog atmetus rūkymą, kaip rizikos veiksni, vis vien išliko statistiškai reikšminga preeklampsijos išsivystymo rizika nėščiosioms, sergančioms lètiniu periodontitu. Kita vertus, pati tyrimo metodika gali būti kritikuojama, nes lètinio periodontito požymiu įvertintas tik CAL $\geq 4 \mathrm{~mm}$.

Sergančiosioms lètiniu periodontitu dažniausiai pasitaikančios nėštumo komplikacijos - priešlaikinis gimdymas ir mažo svorio naujagimiai.

Pattanashetti J. I. ir kt (2013) tyre 200 néščiųų, kurių 100 išsivystė preeklampsija. Sirgusioms sunkiu lètiniu periodontitu ir preeklamsija 25 moterims iš $30(83,3 \%)$ įvyko priešlaikinis gimdymas, kai tuo tarpu nesirgusiujuc preeklamsija grupejje su analogiška apydančio būkle tik 5 iš 20 $(25,0 \%)$ [35]. Tyrimai rodo, kad priešlaikinis gimdymas priklauso nuo periodontito sunkumo laipsnio: sergančiųų lengvo laipsnio periodontitu ir preeklampsija 49,3\% moteru gimdè anksčiau, nei numatyta, o sunkiu periodontitu $-82,6 \%$ [40]. 2010 m. Nabet C. ir kt. pateike panašias išvadas: lètinis periodontitas nèštumo metu susijęs su priešlaikiniu gimdymu dèl preeklampsijos (OR 2,46) [31]. Priešlaikinio gimdymo tikimybè preeklampsija sergančioms néščiosioms tiesiogiai priklauso nuo lètinio periodontito aktyvumo laipsnio [35].

Jau 1996 m. Offenbacher S. pastebèjo lètinio periodontito įtaką mažo svorio naujagimiams gimti [32].

Toygar H. U. ir kt. (2007), išsamiai ištyrę 3576 Turkijos něščįsias, nustatè, kad kuo aukštesnis periodontologinio gydymo reikalingumo indeksas (CPITN), tuo mažesnis naujagimio svoris bei didesnè gimdymo komplikacijų tikimybè [47]. Contreras A. ir kt. tyrimo duomenimis, preeklampsija sergančių nėččiujų naujagimiai vidutiniškai svèrè $2.453 \mathrm{~g}$, kai tuo tarpu sveikujų - $2.981 \mathrm{~g}$ [11]. Panašūs rezultatai gauti nerūkančiujų nėščiujų grupejje [38].

Nors ši sąsaja iki šiol yra tiriama, studijų, prijungiančių ir preeklampsiją, vis dar mažai. O.Yoseffin su bendraautoriais $2010-2011 \mathrm{~m}$. tyre preeklampsijos, periodontito ir mažo svorio naujagimių tarpusavio ryšị. Šio tyrimo duomenimis, rizika susirgti preeklampsija, sergant periodontitu, yra statistiškai 3,17 kartus didesnè, nei esant sveikam apydančiui; kuo sunkesnè periodonto būklè, tuo mažesnis naujagimio svoris. Esant sunkiai lètinio periodontito formai 59,09\% naujagimių svèrè mažiau nei $2500 \mathrm{~g}$ [51].

Literatūroje yra ir prieštaringų duomenų (1 lent.) [20,15,46]. 2012 m. H. A. Schenkein studijoje ištyrus něš- čiąsias, sirgusias lokalizuotu ir generalizuotu agresyviu periodontitu bei sveikujų grupę, atsižvelgiant ị rūkymą, rasę, amžių, nèštumo trukmę, nerasta statistiškai patikimo ryšio tarp agresyvaus periodontito ir naujagimio svorio [43].

Manoma, kad apydančio audinių uždegimas turi įtakos ne tik néštumo metu, bet ir prieš ji [3]. K.A. Boggess su bendraautoriais surinko 470 něščiujų anamnezę apie buvusius ar esamus pakitimus burnoje, higienos icpročius, apsilankymus pas odontologą. Tyrimo rezultatai rodo, kad buvęs periodontito gydymas prieš něštumą yra susijęs su preeklampsija $(\mathrm{OR}=3.71 ; 95 \%$ patikimumo intervalas $(C I)=1.40$ to 9.83$)[3]$. Sis tyrimas parodo tikslios burnos ligų anamnezès surinkimo svarbą.

\section{Išvados}

Remiantis literatūros duomenimis, periodontitas gali būti viena iš nėščiujų preeklampsijos priežasčių. Ryši patvirtinančiose studijose tai grindžiama tipinių periodontito sukèlejų aptikimu preeklampsija sergančių neščiujų kraujotakos sistemoje, amniono skystyje ir placentoje. Klinikinių studijų, tyrusių periodontito ir preeklampsijos ryšs̨, rezultatai prieštaringi. Literatūros autoriai pažymi, jog tikslesniems tyrimų rezultatams ir jų analizei reikalinga suvienodinti etikos normas, nustatyti aiškius periodontito ir preeklampsijos kriterijus, naudoti tą pačią metodologiją. Epidemiologiniai tyrimai, atlikti tiksliai ir išvengiant metodikos trūkumų gali duoti vertingos informacijos apie minètų ligų ryši bei pasiūlyti prevencijos strategiją, kuri padètų sumažinti preeklampsijos atvejų skaičių.

Gydytojai odontologai turètų nepamiršti itin atidžiai atlikti néščiųų dantų ir burnos ertmès apžiūrą, jie pirmieji gali pastebèti ankstyvus apydančio uždegimo požymius. Gydytojo pareiga informuoti moteris apie galimą periodontito žalą něštumo eigai ir jai pačiai, būtina motyvuoti pacientes periodiškai atlikti burnos apžiūrą ir higieną. Svarbu atidžiai apžiūrèti dantenų konsistenciją, spalvą, įvertinti hipertrofijos laipsnį, virš ir podanteninių konkrementų kiekị, kraujavimą zonduojant, kišenių gylį, o prireikus - nukreipti pas gydytoją periodontologą tolimesniam gydymui ir priežiūrai.

\section{Literatūra}

1. Arakawa $\mathrm{S}$, Nakajima $\mathrm{T}$, Ishikura $\mathrm{H}$, Ichinose $\mathrm{S}$, Ishikawa I, Tsuchida N. Novel apoptosis-inducing activity in Bacteroides forsythus: a comparative study with three serotypes of Actinobacillus actinomycetemcomitans. Infect Imum 2000; 68:4611-4615.

2. Baba A, Kadowaki T, Asao T, Yamamoto K. Roles for Arg and Lys-gingipains in the disruption of cytokine responses and loss of viability of human endothelial cells by Porphyromonas gingivalis infection. Biol Chem 2002; 383:1223-1230. 
3. Boggess KA, Lieff S, Murtha AP, Moss K, Beck J, Offenbacher $\mathrm{S}$. Maternal periodontal disease is associated with an increased risk of preeclampsia. Obstet Gynecol 2003; 101(2): 227-31.

4. Barak S, Oettinger-Barak O, Machtei EE, Sprecher H, Ohel G. Evidence of periopathogenic microorganisms in placentas of women with preeclampsia. J Clin Periodontol 2007; 78:670-676

5. Boggess KA, Berggren EK, Koskenoja V, Urlaub D, Lorenz C. Severe Preeclampsia and Maternal Self-Report of Oral Health, Hygiene, Dental Care. 2013 Feb doi: 10.1902/jop.2012.120079.

6. Canakci V, Canakci CF, Canakci H, Canakci E, Cicek Y, Ingec M, Ozgoz M, Demir T, Dilsiz A, Yagiz H. Periodontal disease as a risk factor for pre-eclampsia: a case control study. Aust N Z J Obstet Gynaecol, 2004 Dec;44(6):568-73.

7. Canakci V, Canacki C F, Yildirim A, Ingec M, Eltac A, Erturk A. Periodontal disease increases the risk of severe pre-eclampsia among pregnant women. J Periodontol 2007; 34: 639-645.

8. Chaparro A, Blanlot C, Ramírez V, Sanz A, Quintero A, Inostroza C, Bittner M, Navarro M, Illanes SE. Porphyromonas gingivalis, Treponema denticola and toll-like receptor 2 are associated with hypertensive disorders in placental tissue: a case-control stud. J Periodontal 2013 Dec; 48(6):802-9.

9. Collins JG, Windley HW, Arnold RR, Offenbacher S. Effects of a Porphyromonas gingivalis infection on inflammatory mediator response and pregnancy outcome in hamsters. Infect Immun 1994;62(10):4356 - 4361.

10. Contreras A, Herrera JA, Soto JE, Arce RM, Jaramillo A, Botero JE. Periodontitis is associated with preeclampsia in pregnant women. J Periodontol 2006; 77:182-188.

11. Contreras A, Herrera JA, Soto JE, Arce RM, Jaramillo A, Botero JE. Periodontitis Is Associated With Preeclampsia in Pregnant Women. J Clin Periodontol 2006 Feb; 182-188 doi: 10.1902/ jop.2006.050020

12. Cota LOM, Guimaraes AN, Costa JE, Lorentz TCM, FO. Costa. Association between maternal periodontitis and an increased risk of preeclampsia. J Periodontol 2006; 77: 2063-2069.

13. Ha JE, Oh KJ, Yang HJ, Jun JK, Jin BH, Paik D, Bea K H. Oral health behaviors, periodontal disease, and pathogens in preeclampsia: A Case-Control. J Periodontol 2011; 82:16851692.

14. Hamada S, Amano A, Kimura S, Nakagawa I, Kawabata $\mathrm{S}$, Morisaki I. The importance of fimbriae in the virulence and ecology of some oral bacteria. Oral Microbiol Imunol 1998; 13:129-138.

15. Horton AL, Boggess KA, Moss KL, Beck J, Offenbacher S. Periodontal Disease, Oxidative Stress, and Risk for Preeclampsia. J Periodontol 2010; 81:199-204.

16. Ide M, Papapanou PN. Epidemiology of association between maternal periodontal disease and adverse pregnancy outcomes - systematic review. J Clin periodontol 2013; 40: S181-S194.

17. Jung-Eun Ha, Jong-Kwan Jun, Hyun-Joo Ko, Dai-Il Paik, Kwang-Hak Bae. Association between 45 periodontitis and preeclampsia in never-smokers: a prospective study. J Clin
Periodontol 2014; 41: 869-874 doi: 10.1111/jcpe.12281.

18. Khader YS, Jibreal M, Al-Omiri M, Amarin Z. Lack of association between periodontal parameters and preeclampsi. J Periodontol 2006;77:1681-1687.

19. Kunnen A, van Doormaal JJ, Abbas F, Aarnoudse JG, van Pampus MG, Faas MM. Periodontal disease and pre-eclampsia: A systematic review. J Clin Periodontol 2010; 37:1075-1087

20. Lafzi A, Eskandri A, Abolfazli N, Khashabi E, Golmohammadi S. Relationship between preeclampsia and periodontal disease. J Periodontol Implant Dent 2011; 3(2):79-82.

21. Lamont RJ, Jenkinson HF. Subgingival colonization by Porphyromonas gingivalis. Oral Microbiol Imunol 2000; 15:341 -349 .

22. Lin D, Smith MA, Elter J, Champagne Ch, Downey CL, Beck J, Offenbacher S. Porphyromonas gingivalis infection in pregnant mice is associated with placental dissemination, an increase in the placental Th1/Th2 cytokine ratio, and fetal growth restriction. Infect Imum 2003; 71:5163-5168.

23. Lin D, Smith MA, Elter J, Champagne Ch, Beck J, Offenbacher SS. Porphyromonas gingivalis infection during pregnancy increases maternal tumor necrosis factor alpha, suppresses maternal interleukin-10, and enhances fetal growth restriction and resorption in mice. Infect Imum 2003; 71:5156-5162.

24. Lonsoonthon V, Kungsadalpipob K, Chanchareonsook P, Limpongsanurak S, Vanichjakvong O, Sutdhibhisal S, Sookprome Ch, Wongkittikraiwan N, Kamolpornwijit W, Jantarasaengaram S, Manotaya S, Siwawej V, Barlow WE, Fitzpatrick AL, Williams M. Maternal periodontal disease and risk of preeclampsia: A Case - Control Study. American Journal of Hypertension 2008; 22(4):457-463.

25. Lourbakos A, Yuan YP, Jenkins AL, Travis J, Andrade-Gordon P, Santulli R, Potempa J, Pike RN. Activation of protease-activated receptors by gingipains from Porphyromonas gingivalis leads to platelet aggregation: a new trait in microbial pathogenicity. Blood 2001; 97:3790-3797.

26. Madianos PN, Bobetsis YA, Offenbacher S. Adverse pregnancy outcomes (APOs) and periodontal disease: pathogenic mechanisms. J Clin periodontolm 2013; 40: S170 - S180.

27. Michalowicz BS, Gustafsson A, Thumbigere - Math V, Buhlin $\mathrm{K}$. The effects of periodontal treatment on pregnancy outcomes. J Clin periodontol 2013; 40: S195-S208.

28. Mokeem SA, Molla G, Al-Jewair T. The prevalence and relationship between periodontal disease and preterm low birth weight infants at King Khalid University Hospital in Riyadh, Saudi Arabia. J Contemp Dent Prac 2004;2(5):40-56.

29. Moncla BJ, Braham P, Rabe LK, Hillier SL. Rapid presumptive identification of black-pigmented gram-negative anaerobic bacteria by using 4-methylumbelliferone derivatives. J Clin Microbiol 1991; 29:1955-1958.

30. Moura da Silva G, Coutinho SB, Piscoya MDBV, Ximenes RAA, Jamelli SR. Periodontitis as a risk factor for preeclampsia. J Clin periodontol 2012; 83: 1388-1396.

31. Nabet C, Lelong N, Colombier ML, Sixou M, Musset AM, 
Goffinet F, Kaminski M. Maternal periodontitis and the causes of preterm birth: the case-control Epipap study. J Periodontol 2010; 37(1):37-45.

32. Offenbacher S, Katz V, Fertik G, Collins J, Boyd D, Maynor G. et al. Periodontal infection as a possible risk factor for preterm low birth weight. J Periodontol 1996; 67(10 Suppl):1103-1113.

33. Offenbacher S, Lieff S, Boggess KA, Murtha AP, Madianos $\mathrm{PN}$, Chmpagne CM. et al. Maternal periodontitis and prematurity. Part I: obstetric outcome of prematurity and growth restriction. Ann Periodontol 2001;6:164-74.

34. Offenbacher S, Beck JD, Lief S, Slade GS. Role of periodontitis in systemic health: spontaneous preterm birth. J Dent Educ 1998; 62(10):852-58.

35. Pattanashetti JI, Nagathan VM, Rao SM. Evaluation of Periodontitis as a Risk for Preterm Birth among Preeclamptic and Non-Preeclamptic Pregnant Women - A Case Control Study. J Clin Diagn Res. 2013 Aug; 7(8): 1776-1778.

36. Pham K, Feik D, Hammond BF, Rams TE, Whitaker EJ. Aggregation of human platelets by gingipain-R from Porphyromonas gingivalis cells and membrane vesicles. Platelets 2002; 13:21-30.

37. Politano GT, Passini R, Nomura ML, Velloso L, Morari J, Couto E. Correlation between periodontal disease, inflammatory alterations and pre-eclampsia. J Periodontal Res. 2011; 46(4):505-11.

38. Rakoto-Alson S, Tenenbaum H, Davideau JL. Periodontal Diseases, Preterm Births, and Low Birth Weight: Findings From a Homogeneous Cohort of Women in Madagascar 2010 Feb; 81(2): 205-213, DOI 10.1902/jop.2009.090351.

39. Reingardienė D. Preeklampsija ir eklampsija. Medicina, 2003; 39:12.

40. Riche EL, Bogess KA, Lieff S. Periodontal disease increases the risk of preterm delivery among preeclamptic women. Ann Periodontol 2002;7:95-101.

41. Sayar F, Hoseini MS, Abbaspour S. Effect of periodontal disease on preeclampsia. Iranian J Public Heatlh 2011; 40(3):122-127.

42. Sanz M, Kornman K. and on behalf of working group 3 of the joint EFP/AAP workshop. Periodontitis and adverse pregnancy outcomes: consensus report of the joint EFP/AAP workshop of periodontitis and systemic diseases. J Clin periodontol, 2013; 40: S164 - S169.

43. Schenkein HA, Koertge TE, Sabatini R, Brooks CN, Gunsolley JC. Birth Weight of Infants of Mothers With Aggressive Periodontitis 2012 Mar; 83(3): 279-286, DOI 10.1902/ jop.2011.110192

44. Siqueira FM, Cota M, Costa JE, Amaral JP. Maternal periodontitis as a potential risk variable for preeclampsia: A CaseControl Study. J Periodontol 2008; 79:207-215.

45. Swati P, Thomas B, Vahab SA, Kapaettu S, Kushtagi P. Simultaneous detection of periodontal pathogens in subgingival plaque and placenta of women with hypertension in pregnancy. Arch Gynecol Obstet 2012 Mar; 285(3):613-9.
46. Taghzouti N, Xiong X, Gornitsky M, Chandad F, Voyer R, Gagnon I, Leduc L, Xu H, Tulandi T, Wei B, Senecal J, Velly A, Salah M, Fraser WD. Periodontal disease ir nor associated with preeclampsia in Canadian prengnant women. J Periodontol 2012;83:871-877.

47. Toygar HU, Seydaoglu G, Kurklu S, Guzeldemir E, ArpakN. Periodontal Health and Adverse Pregnancy Outcome in 3,576 Turkish Women. 2007 Nov; 78(11):2081-2094, DOI 10.1902/ jop.2007.070092

48. van Winkelhoff AJ, Loos BG, van der Reijden WA, van der Velden U. Porphyromonas gingivalis, Bacteroides forsythus and other putative periodontal pathogens in subjects with and without periodontal destruction. J Clin Periodontol 2002; 29(11):1023-1028.

49. Williams CECS, Davenport ES, Sterne JAC, Shivapathsundram $\mathrm{V}$, Fearne JM, Curtis MA. Mechanisms of risk in preterm low birth weight infants. Periodontol 2000. 2000;23:142-50.

50. Yoseffin O, Gusriani G, Mose JC. Correlations of chronic periodontitis with preeclampsia and fetal birth weight. Obstet Gynecol 2011; 35-3: 105-9.

51. Internetinè prieiga: http://www.pasveik.lt/lt/naujienos/nestumosukelta-hipertenzija-ir-preeklampsija/72794

\section{RELATIONSHIP BETWEEN PREECLAMPSIA AND PERIODONTAL DISEASE}

\section{M. Pacauskienė, E. Stasiukonè, B. Vaišvilaitė}

Key words: periodontitis, preeclampsia, preterm birth, low birth weight.

Summary

This review evaluates the possible relationship between periodontal disease and adverse pregnancy outcomes, especially pre-eclampsia, a major pregnancy complication.A literature search of electronic databases PubMed (www.ncbi.nlm.nih.gov/ pubmed), „Journal of Periodontology“ (www.joponline.org) was performed for articles published 2002 to 2014. 22 studies analizing relationship between periodontitis and pre - eclampsia were included, including 19 case - control studies and 3 systematic reviews. 5 studies (case - controls) analizing relationship between periodontitis and pregnant women with pre-eclampsia included. 10 studies (case - controls) analizing relationshiop between periodontitis and adverse pregnancy outcomes included. 17 sudies reported positive association between periodontitis and preeclampsia, while 5 studies showed no significant association. 5 studies found positive association between periodontitis and pregnant women with pre - eclampsia. 6 studies reported possitive association between periodontitis and adverse pregnancy outcomes, 4 studies showed no significant association. It appeared difficult to compare these studies, due to variations in definitions of periodontal disease and pre-eclampsia, differences of methodology and different characteristics of studied groups. Further studies for stronger evidence are required.

Correspondence to: ingridapacauskiene@takas.lt

Gauta 2015-04-01 